Published in final edited form as:

Microbiol Spectr. 2016 November ; 4(6): . doi:10.1128/microbiolspec.MCHD-0034-2016.

\title{
Complement receptors in myeloid cell adhesion and phagocytosis
}

\author{
Michael L. Dustin \\ Kennedy Institute of Rheumatology, Nuffield Department of Orthopedics, Rheumatology and \\ Musculoskeletal Sciences, The University of Oxford, Roosevelt Drive, Headington, OX3 7FY
}

\section{Abstract}

Myeloid cells make extensive use of the complement system in the context of recruitment, phagocytosis and other effector functions. There are several types of complement receptors on myeloid cells including G-proteins coupled receptors for localizing the source of complement activation, and three sets of type I transmembrane proteins that link complement to phagocytosiscomplement receptor 1, a single chain type I membrane protein with tandem complement regulatory repeats, complement receptors 3 and 4 , which are integrin family receptors comprised of heterodimers of type I transmembrane subunits, and VSIG4, member of the Ig-superfamily. This review will focus the role of the different classes of complement receptors and how their activities are integrated in the setting of immune tolerance and inflammatory responses.

\section{Introduction}

Complement is a system of blood plasma proteins that play critical roles in host defense through attracting leukocytes to sites of inflammation, mediating myeloid cells uptake and destruction of microbes, and guiding B and T cell activation $(1,2)$. Regardless of the activation mechanism, the complement cascade converges on generation of $3^{\text {rd }}$ component of complement ( $\mathrm{C} 3$ ) convertases that cleave $\mathrm{C} 3$ to $\mathrm{C} 3 \mathrm{a}$ and $\mathrm{C} 3 \mathrm{~b}$. $\mathrm{C} 3 \mathrm{~b}$ consists two subunits containing 8 macroglobulin-like domains (MG1-8). The $\beta$ subunit consists of MG1-MG5 plus the N-terminal half of MG6. The a subunit start with the C-terminal half of MG6, a $\mathrm{C} 1 \mathrm{r} / \mathrm{C} 1 \mathrm{~s}$, Uegf and Bone morphogenetic protein-1 (CUB) domain and a Thioester domain (TED) inserted between MG7 and MG8, followed by the "anchor" and C345C domain (trapezoid in Figure 1).

Classical antibody mediated, lectin mediated and the alternative thioester hydrolysis mediated pathways for complement activation operate through self-amplifying zymogen cascades focused around proteolytic processing of $\mathrm{C} 3$ to generate $\mathrm{C} 3$ convertases that include $\mathrm{C} 3 \mathrm{~b}$. The activating step is cleavage of $\mathrm{C} 3$ to $\mathrm{C} 3 \mathrm{a}$ and $\mathrm{C} 3 \mathrm{~b}$. This results in a large conformational change in the TED domain that exposes the thioester bond and this reacts covalently to immune complexes and microbial surfaces (3). The proteases that mediate this cleavage include components of $\mathrm{C} 1 \mathrm{q}$ in antibody mediated complement activation (classical pathway), mannose-binding protein by surfaces such as yeast cell walls (lectin pathway) and hydrolysis of the thioster bond in soluble $\mathrm{C} 3$ the alternative pathway. $\mathrm{C} 3 \mathrm{~b}$ then partners with $\mathrm{C} 4 \mathrm{~b}$ or $\mathrm{C} 5 \mathrm{~b}$ to form complexes that convert more $\mathrm{C} 3$ to $\mathrm{C} 3 \mathrm{a}$ and $\mathrm{C} 3 \mathrm{~b}$ to amplify the response. The $\mathrm{C} 3$ convertases also activates $\mathrm{C} 5$ to $\mathrm{C} 5 \mathrm{a}$ and $\mathrm{C} 5 \mathrm{~b}$, with $\mathrm{C} 5 \mathrm{~b}$ leading to 
assembly of the pore forming membrane attack complex by C6-C9. The small, soluble C3a and C5a fragments are referred to as "anaphylatoxins" and play an important role as chemoattractants for myeloid cells.

Host cells express a number of regulatory factors that inhibit the complement cascade at different steps, either by blocking formation of the $\mathrm{C} 3$ convertases, accelerating their inactivation or blocking effector mechanisms such as membrane attack complex assembly. This protects host cells to some extent from background complement activation and means that the alternative pathway activation can target microbial surfaces lacking these regulatory components by a "missing self" process. Complement deposition mediated by the classical pathway can overcome this regulation and damage host cells in the context of autoimmunity or excessive immune complex formation. Some of the complement receptors we will discuss also act as regulatory components.

Soluble C3a, C3b clusters, and the covalently attached breakdown products of C3b, anchored to microbial surfaces serve as ligands for three groups of type I transmembrane complement receptors $(2,4)$. Complement receptors 1 and 2 (CR1 and CR2) are members of the SCR family, complement receptor 3 and 4 (CR3 and CR4) are members of the integrin family and Complement Receptor Immunoglobulin-like (CRIg), which we will refer to using its gene name as Variable-set immunoglobulin-like domain 4 (VSIG4) is a member of the immunoglobulin superfamily. Human CR1 is highly expressed on myeloid cells in additional to erythrocytes, whereas VSIG4 is expressed on selected macrophage subpopulations including Kupffer cells in the liver and peritoneal macrophages in the mouse and macrophages and mast cells in humans (http://www.immgen.org). Further processing of C3b by Factor I to iC3b (attached) and C3f (released) and then two C3d (attached) and C3c (released) through a second cleavage. $\mathrm{C} 3 \mathrm{~b}, \mathrm{iC} 3 \mathrm{~b}$ and $\mathrm{C} 3 \mathrm{~d}$ tend to cluster on microbial surfaces due to the focal nature of the amplification process and this clustered configuration is optimal for CR3 function (4). CR3, CR4 and VSIG4 all bind to iC3b. C3d is a ligand for CR2 and CR3. Human CR2 is expressed on B cells and follicular dendritic cells and interacts with C3d on soluble immune complexes, whereas CR3 and CR4 interact with clustered $\mathrm{iC} 3 \mathrm{~b}$ on opsonized particles in different ways (5-7). CR3 retains binding to C3d, which is essentially the TED domain of C3, whereas VSIG4 and CR4 binds to C3c, which is released as a soluble fragment when $\mathrm{iC} 3 \mathrm{~b}$ is cleaved a second time by factor I (8). Due to the low affinity of these interactions its unlikely that soluble $\mathrm{C} 3 \mathrm{c}$ will interfere significantly with binding to clusters $\mathrm{iC} 3 \mathrm{~b}$ on surfaces.

While acting as complement receptors in adhesion and phagocytosis, CR1 and VSIG4 both have regulatory activity. CR1 is a co-factor for factor I mediated cleavage of C3b to iC $3 b$ and VSIG4 blocks the interaction of $\mathrm{C} 3 \mathrm{~b}$ in the alternative pathway $\mathrm{C} 3$ convertase with $\mathrm{C} 5$ which is necessary for the alternative pathway of complement activation to mediate C5a release and formation of membrane attach complexes (9). Thus, VSIG4 is a negative regulator of complement activation by the alternative pathway (10). Interestingly, VSIG4 is also studied as a checkpoint regulator for T cell activation through an unknown mechanism, although assumed to be a checkpoint receptor like Programmed death 1 or Cytotoxic T lymphocyte Antigen-4 (11). We will discuss this effect of VSIG4 in the context of proposed roles for complement proteins in $\mathrm{T}$ cell activation. This chapter will attempt to reconcile 
what we know about the cellular distribution of these myeloid cell complement receptors, their biophysical capabilities and data on their contributions to immune responses in vivo.

\section{G-protein coupled receptor family}

$\mathrm{C} 3 \mathrm{a}$ and $\mathrm{C} 5 \mathrm{a}$ are small, basic 4 helix bundle proteins that bind to synonymous GPCR C3aR and C5aR (12). GPCR are a large family of multi-spanning transmembrane receptors with an extracellular N-terminus lacking a signal peptide, 7 trans-membrane helices, and a Cterminal cytoplasmic domain. The extracellular $\mathrm{N}$-terminus and loops form a ligand binding surface that mediates a conformational change in the trans-membrane helices that is directly transmitted to the cytoplasmic loops and C-terminus, where hetero-trimeric G-proteins are docked. Ligand binding to the GPCR liberates the a subunit of the hetero-trimeric Gprotein, leaving the active $\beta \gamma$ complex, which can activate phosphatidylinositol-3 kinase and phospholipase $\mathrm{C}-\beta$ associated with the receptor. $\mathrm{C} 3 \mathrm{aR}$ and $\mathrm{C} 5 \mathrm{aR}$ are coupled to signal transduction pathways primarily through pertussis toxin sensitive $G_{a i}(13)$. It has been shown that C5aR also activates p38 mitogen activated kinase and this inhibits chemotaxis to leukotriene B4 and interleukin-8. It is thought that this p38 mediated signaling prioritizes the microbe targeting C5a gradient over host cell derived attractants that provide more general guidance into the tissue (14). C3aR and C5aR are both highly expressed on basophils and more moderately expressed on mast cells and smooth muscle cells. C3aR is expressed strongly on thioglycolateelicited macrophages in mice and at lower levels on dendritic cells and other macrophage populations. C5aR is highly expressed on neutrophils and a wide range of tissue macrophages, and more moderately on monocytes. C3aR and C5aR are also coupled to contraction in smooth muscle cells through a cascade involving release of the nucleotide uracyldiphosphate (UDP), which binds to a receptor couple of $\mathrm{G}_{\mathrm{aq}}$, phospholipase $\mathrm{C}-\beta$ and $\mathrm{Ca}^{2+}$ elevation (15). Due to its expression pattern in neutrophils and monocytes, C5aR is particularly important in recruitment of leukocytes into sites of inflammation. $\mathrm{C} 3 \mathrm{aR}$ and $\mathrm{C} 5 \mathrm{aR}$ are reported to play a role in $\mathrm{T}$ cell activation as will be discussed below (16), but microarray and RNA sequencing data in mouse suggests very low expression compared to macrophages $(\mathrm{C} 3 \mathrm{aR})$ or macrophages and neutrophils $(\mathrm{C} 5 \mathrm{aR})$. Both $\mathrm{C} 3 \mathrm{a}$ and C5a can be further processed by caboxy-peptidases to yield des-arg forms with modified biological activity (17). There is a second C5aR, referred to as C5L2 (encoded by gene C5AR2), which is either a decoy receptor that removes C5a and may reinforce gradients, or may also directly modulate the activity of C5aR by recruiting $\beta$-arrestin (18). In other systems, decoy receptors can be involved in setting up gradients (19), but this is not established for C5L2.

Genetic studies demonstrate non-redundant roles of $\mathrm{C} 3 \mathrm{aR}$ and $\mathrm{C} 5 \mathrm{aR}$ in various pathological settings. C3aR has a pronounced role in allergic inflammation in mouse models and C3a is particularly abundant in lavage fluid of humans exposed to allergens (20). C5aR has a nonredundant role in protection of the host against bacterial pathogens at mucosal surfaces, which goes beyond neutrophil recruitment (21). Either C3aR or C5aR deficiency in mice reduced the severity of collagen-induced arthritis in mice, with C5aR appearing to play a greater role (22). Consistent with this, antibody mediated blockade of C5aR eliminates mouse collagen induced arthritis and reduces levels of multiple cytokines (23). However, 
attempts to treat human rheumatoid arthritis with a small molecule C5aR antagonist were not successful (24).

\section{Short consensus repeat (SCR) superfamily}

Many complement regulatory proteins, scavenger receptors and a family of low-density lipoprotein like receptors share a repeated domain referred to as a short-consensus repeat (SCR). The SCR domain is $\sim 60$ amino acids long and has $6 \beta$-strands in two $\beta$-sheets stabilized by 2 highly conserved disulfide bonds. CR1 (CD35) and CR2 (CD21) have extracellular domains that are entirely composed of long homologous repeats (LHR) containing 6-7 SCRs that reflect functional complement proteins binding units. The genomic structure of the loci encoding CR1 and CR2 are different in primates (including humans) and non-primates (including mice), making mouse models only partially applicable to the human situation (25) (Figure 2).

In mice and other non-primates, CR2 consists of 4 LHR and binds C $3 \mathrm{~d}$ on immune complexes. The expression of mouse CR2 protein is largely restricted to B cells (26). In contrast, follicular dendritic cells (FDC), a stromal cell type that define the B cell follicle and retains immune complexes on their surface for capture by germinal center B cells, express the $\mathrm{CR} 1$ protein based on alternative splicing that adds an additional LHR that binds $\mathrm{C} 3 \mathrm{~b}$ and $\mathrm{C} 4 \mathrm{~b}$ (26). This N-terminal LHR is highly related to a distinct and more widely expressed $\mathrm{C} 4 \mathrm{~b}$ and $\mathrm{C} 3 \mathrm{~b}$ binding protein called Crry (also referred to as CR1-like, or CR1L). Both the N-terminal LHR of mouse CR1 and the single LHR of Crry have co-factor activity for Factor I, and thus have an important role in control of $\mathrm{C} 3$ convertase activity by converting $\mathrm{C} 3 \mathrm{~b}$ into $\mathrm{iC} 3 \mathrm{~b}$ and $\mathrm{C} 3 \mathrm{~d}(25)$, although a number of soluble and surface bound complement regulatory factors also inhibit or facilitate inactivation of $\mathrm{C} 3$ convertases. Neither mouse CR1 or CR2 are highly expressed in myeloid cells. Crry is expressed on myeloid cells, but at moderate levels and has not been clearly associated with effector functions like adhesion or phagocytosis.

In humans, a distinct gene encodes the CR1 mRNA and protein with 3-6 C4b and/or C3b binding LHRs in different allelic variants- with 4 LHR in the most common alleles (27). Human CR1 is widely expressed, including on myeloid cells, erythrocytes and some epithelial cells. For example, on the surface of kindey podocytes, CR1 facilitates the conversion of $\mathrm{C} 3 \mathrm{~b}$ to $\mathrm{C} 3 \mathrm{~d}$ with a half time of about 30 minutes in vitro, potentially contributing to protection of the kidney filtration apparatus from immune complex mediated damage along with other regulators such as decay accelerating factor (28). Monomeric C3b binds to CR1 LHRs with a $\mathrm{K}_{\mathrm{d}}$ in the $10^{-6} \mathrm{M}$ range in physiological salt conditions (29). Caution is needed in reading the literature as measurements are often performed with oligomeric forms of $\mathrm{C} 3 \mathrm{~b}$ and/or at low salt where the apparent $\mathrm{K}_{\mathrm{d}}$ is in the $10^{-9} \mathrm{M}$ range (29). Thus, CR1 is a high avidity receptor for polyvalent binding to clustered ligands on immune complexes or surfaces. The low affinity and fast off rate is typical of surface receptors that bind multivalent or particulate ligands.

Given the differences between mouse and human CR1 genes, it is difficult to predict the function of human CR1 based on mouse models and knockout mice. Mice deficient in all 
variants of CR1 and CR2, but expressing Crry, have impaired B cells responses, including loss of IgG3 and are more susceptible to Pseudomonas mediated pneumonia than wild type mice (30). Mice lacking only CR1 on FDC have milder defects and are not as susceptible to Pseudomonas pneumonia as mice lacking both CR1 and CR2 (26). The role of CR1 in myeloid cell's effector functions, such as phagocytosis, can't be studied in mice although mice expressing human CR1 on erythrocytes demonstrate a role in immune complex clearance (31).

In vitro studies with human neutrophils and macrophages demonstrate that CR1 plays a role in phagocytosis $(6,32)$, in parallel with CR3 (see below). There is a general concept that phagocytosis mediated by $\mathrm{CR} 1$ requires activation of the myeloid cell either through $\mathrm{Fc}$ receptors or other immunoreceptors or through prior activation/differentiation of the myeloid cell (33). CR1 is more clustered on erythrocytes compared to neutrophils (34). Erythrocytes shuttle immune complexes from the blood to phagocytes in the liver and spleen. The greater basal clustering of CR1 on erythrocytes may enable greater binding of soluble immune complexes, whereas neutrophils with less basal clustering bound few $\mathrm{C}_{3} \mathrm{~b}^{+}$immune complexes despite higher CR1 expression. Activation of neutrophils with the chemotactic tri-peptide formyl-methionine-leucin-phenylanaline increased CR1 expression, but didn't increase its clustering. The potential importance of clustering in ligand discrimination is consistent with the relatively low affinity and transient interaction of monomeric $\mathrm{C} 3 \mathrm{~b}$ with single CR1 LHR. CR1 has a short cytoplasmic domain that has received surprisingly little detailed attention, although studies suggest that CR1 participates in phospholipase $\mathrm{C}$ activation (6). The C-terminus of CR1 interacts with the PDZ domains of FAP-1 in erythrocytes, which may account for CR1 clustering (35). The biophysical implications for the large size of CR1 in the context of immune-receptor signaling will be discussed further below.

\section{Integrin family complement receptors}

Integrins are a large family of hetero-dimeric trans-membrane glycoproteins expressed in vertebrates and some invertebrates (36). They are specialized for cell-extracellular matrix and cell-cell adhesion and particularly the integration of adhesion with the cytoskeleton, transduction of mechanical signals and transmission of force to the cells environment (37). Ligand binding by integrins is unique among complement receptors in being metal ion dependent. In the immune system, physical processes such as leukocyte extravasation, some modes of interstitial migration and phagocytosis of particles by myeloid cells are dependent upon members of the integrin family. Sub-families of integrin family adhesion molecules are organized around shared subunits with both subunits contributing to ligand specificity and specific cytoskeletal interactions that define functions. The subunits are named in the traditional biochemical convention with the larger subunit referred to as $a$ and the smaller as $\beta$ and then subscripts are used to designate the specific gene products that make up the receptor (38). For example, pairing of the $\alpha_{M}$ (gene ITGAM) and $\beta_{2}$ (gene ITGB2) subunits forms $\mathrm{CR} 3$, the major receptor for the $\mathrm{iC} 3 \mathrm{~b}$ and the further breakdown product $\mathrm{C} 3 \mathrm{~d}$, whereas pairing of $\alpha_{X}$ (ITGAX) and $\beta_{2}$ (ITGB2) subunits forms CR4, a receptor with affinity for $\mathrm{iC} 3 \mathrm{~b}$, but not $\mathrm{C} 3 \mathrm{~d}$. The key role of integrins in myeloid cells function is dramaticaly illustrated by the primary immunodeficiency Leukocyte adhesion deficiency type 1 (LAD1), 
in which four leukocytes integrins, including CR3 and CR4, are deficient due to mutation or deletion of the shared $\beta 2$ subunit (39). These patients suffer recurent bacterial infections and die in childhood unless treated by allogeneic bone marrow translantation. The $\beta 2$ integrins play key roles in the extravasation of blood born leukocytes through binding intercellular adhesion molecule- 1 and other ligands on endothelial cells. Thus, interpreting the phenotype of LAD1 patients required consideration of both the complement type and non-complement ligands. Myeloid cells also express a number of other integrin family members that function through interactions with extracellular matrix proteins, cell surface adhesion ligands and transforming growth factor- $\beta$ activation (40), as will be discussed below.

\section{Integrin structure}

Integrin a subunits are type I trans-membrane proteins with an $\mathrm{N}$-terminal $\beta$-propeller domain, a series of globular domains forming a large, segmented leg connected to the single trans-membrane domain and short cytoplasmic domain (41). Some of the a subunits, including CR3 and CR4, have an insertion into the $\beta$ propeller domain of a 200 amino acid inserted or I domain with a "dinucleotide binding fold"- essentially a $\beta$-sheet flanked by 7 a-helices $(7,36)$. Divalent metal ion binding EF hands are present in the $\beta$-propeller domain and a single divalent metal ion binding metal dependent adhesion site (MIDAS) is present at the apex of the I-domain. The typically smaller $\beta$ subunit has a conserved dinucleotide binding fold (I-like) domain inserted into the "hybrid" domain that is connected to both the $\mathrm{N}$ - and $\mathrm{C}$-terminus of the I-like domain. Changes in the angle of the hybrid domain with respect to the I-like domain shift the $\mathrm{C}$-terminal $\mathrm{a}$-helix of the I-like domain and change the conformation of the MIDAS and affinity for divalent cation dependent ligand binding (41). This hybrid domain links to a segmented leg domain characterized by an abundance of disulfide bonds, a single trans-membrane domain and a short cytoplasmic domain. When the $a$ and $\beta$ subunits are pairs the $a$-subunits $\beta$-propeller domain and the $\beta$-subunit I-like domain come together to form a single globular headpiece, from which the hybrid domain projects with a variable angle. The segmented leg domains can be either extended or bend at an intersegment genu. When the legs are straight the integrin headpiece is projected $\sim 20 \mathrm{~nm}$ from the cell surface, making it a large structure on the cell surface, but when the genu is bent the headpiece is held a few $\mathrm{nm}$ from the cell surface. The trans-membrane domains are together in the genu bent conformation whereas they are separated in the extended form such that cytoplasmic interactions that cause the integrin to extend are thought to separate the trans-membrane domains by disrupting weak interactions between the trans-membrane domains and the membrane proximal segments of the cytoplasmic domains (the "clasp"). The ligand binding subunit of integrins lacking a I domains bind ligands with the RGD core sequence (or similar with a conserved D or E) that are extended from globular protein domains on loops. The a subunit I domain is the ligand binding site for integrins with this insertion. The conformational change in the headpiece apparently operates like a "bell rope" at the $\mathrm{C}$-terminal end of the I domain to alter its conformation and ligand binding properties by moving the T-terminal $a$-helix to control the conformation of the ligand binding site. The MIDAS motifs bind either $\mathrm{Mg}^{2+}$ in CR3 and CR4. The divalent cation coordinates with a key acidic residue in the ligand to complete the metal coordination. The affinity for ligand is low when the hybrid domain is close to the $a$-subunit thigh domain (closed $=$ bell rope 
slack) or high affinity when the hybrid domain is pulled away from the thigh domain (open $=$ bell rope tight) (42). Then range of affinities that can be achieved varies with the particular integrin ligand pair and functional context. Cryoelectron microscopy of integrins has revealed additional possible structures, one of which appears to crouch, rather than genuflect, and may be capable of binding ligand in close membrane contacts (43).

The cytoplasmic tails of integrins bind to a number of proteins, but the best defined is talin, which has a N-terminal trefoil FERM domain and a long tail that may set the optimal spacing for functional integrin clusters $(44,45)$. Talin binds to a membrane proximal motif in the $\beta 2$ cytoplasmic domain that is associated with integrin extension (44). Talin forms a bridge between the engaged integrin and F-actin (46). It was first described in focal adhesion, but is also prominently accumulated with the immunological synapse between $\mathrm{T}$ cells and B cells (47). Talin is required for CR3 mediated phagocytosis (48). Application of forces to talin through the link between the extracellular matrix and actin-myosin contractile machinery exposes binding sites for vinculin, which translates force exerted on talin into a biochemical binding event and signal (49). The force required to induce vinculin binding is $5 \mathrm{pN}$. Thus, CR3 and CR4 may impart mechanical sensitivity to the phagocytosis process. Force sensing is also important for bacterial adhesion through fimbria protein FimH (50), which interacts with the Ig-family ligand CD48 on phagocytes and diverted internalized bacteria into non-acidified organelles in which the can survive within the phagocyte (51).

\section{Leukocyte Integrins}

Integrin subfamilies are defined by three subunits that engage in the most functional heterodimers. These are the $a V, \beta 1$ and $\beta 2$. Members of each of these families are expressed on leukocytes, but the $\beta 2$ subfamily is restricted to leukocytes (with the exception of some transformed stromal cells) and is thus referred to as the leukocyte integrin subfamily. We can discuss all three subfamilies in terms of functional relevance to myeloid cells, but the complement binding integrins are members of the $\beta 2$ subfamily as discussed already.

The $\beta 2$ integrins were first identified by monoclonal antibodies to myeloid differentiation antigens and lymphocytes function associated antigens, which were selected by on inhibition of CTL mediated killing (38). Springer was the first to note that these distinct heterodimers were related by a shared $\beta$ subunit and subsequently the cloning of the cDNA for the $\beta 2$ subunit defined the integrin family after the $\beta 1$ (CD29) subunit was cloned by Hynes (52). There are 4 members of the $\beta 2$ subfamily: aL (lymphocyte function associated antigen-1, LFA-1, CD11a/CD18), aM (Mac-1, CR3, CD11b/CD18), aX (p150/95, CR4, CD11c/ $\mathrm{CD} 18)$ and $\mathrm{aD}$ (CD11d/CD18). For simplicity we will use LFA-1, CR3, CR4 and CD11d to refer to these hetero-dimers as these are the most relevant for this discussion around myeloid complement receptors. There are function-blocking antibodies to CD18, which will act on all heterodimers and blocking antibodies to the a subunits that are specific for individual heterodimers.

The same screens that generated function blocking antibodies to LFA-1 also identified another set of heterodimers that identified based on expression on the activated lymphocytes, but not on most lymphocytes freshly isolated from blood. These antigens were expressed 
"late" in activation of lymphocytes after the cells had undergone clonal expansion and became post-mitotic effects cells and where thus called very late activation antigens (VLA) (53). These turned out to be $\beta 1$ integrins and the literature still contains many references to VLA-4 (a4 $\beta 1$ ), which is the target for an important therapeutic antibody used in treatment of multiple sclerosis (54).

There are a number of useful antibodies to $\beta 2$ integrins in addition to the function blocking antibodies (55). For example, KIM127 is an epitope on the $\beta 2$ subunit calf domain that only binds to the extended conformation due to masking of the epitope in the genuflected conformation (56). Thus, it can be used to study the temperature and activation dependent extension of the $\beta 2$ integrins. Monoclonal antibody 24 (MAb 24) binds to the hybrid domain of the $\beta 2$ subunit (8). MAb 24 binding stabilizes the high affinity open conformation and is also induced by ligand (57). Thus, it has a net activating effects on integrin-mediated adhesion, but the prolongation of the high affinity state may impair some functions. The conformation specific antibodies have been useful tools in analyzing the location of different conformations on cells (58). Caution is needed as both KIM127 and MAb24 are synergistic with ligand in stabilizing extended or high affinity forms of $\beta 2$ integrins.

LAD1, which was mentioned earlier, is the result of a variety of mutations in the subunit $\beta 2$ subunit that either eliminate the protein completely or reduce expression (59). The $\alpha$ and $\beta$ subunits assembly in the endoplasmic reticulum and when the $\beta$ subunit is absent the $a$ subunit is not expressed on the surface. The consequence of this deficiency is the inability to recruit myeloid cells into sites of inflammation in the gingiva and the skin- resulting in lack of pus formation and life threatening bacterial infections. The condition can be effectively treated by bone marrow transplantation and functional defects lymphocyte may account for a higher success rate for bone marrow transplantation despite the history of the patients with infections (60). The major defect driving this disease appears to be the localization of polymorphonuclear leukocytes to some, but not all, inflamed tissues.

A third variant of Leukocyte adhesion deficiency to be described, LAD3, is based on the deficiency of the $\beta 2$ cytoplasmic domain binding protein kindlin 3 and results in a disease that combines features of LAD1 and platelet function deficiency such as Glanzmann thrombasthenia due to the role of kindlin3 in the function of leukocyte and platelet integrins (61). Kindlin3, encoded by gene FERMT3, is related to talin, but binds to a distinct motif that is more distal from the membrane. While binding of talin alone is sufficient for integrin extension, binding of both talin and kindlin 3 is required to generate the high affinity form of leukocyte and platelet integrins. Kindlin 3, like talin, is also required for phagocytosis and signaling mediated by CR3 (62).

The most widely expressed leukocyte integrin is LFA-1. It is expressed on essentially all leukocytes and is important for anchorage of some cells in the vasculature, extravasation and cell-cell interactions. Its ligands are referred to as intercellular adhesion molecules (ICAM)of which there are 5. The major ligands with demonstrated functions are ICAM-1 (CD54), ICAM-2 (CD105) and ICAM-3 (CD50). ICAM-1 is also a ligand for CR3, although LFA-1 and CR3 binding to different regions within ICAM-1 $(63,64)$. All of the ICAMs are members of the immunoglobulin (Ig)-superfamily, which share variable numbers of $\sim 100$ 
amino acid $\beta$ sandwich domains. ICAM-1 and ICAM-2 are highly expressed on vascular endothelial cells, whereas ICAM-3 is mostly expressed on leukocytes in human, but a similar gene has not been identified in rodents. ICAM-1 expression is regulated by inflammatory cytokines, lymphocytes and by leukocyte activation (65). ICAM-2, in contrast, is constitutively expressed on endothelial cells and some leukocytes (66). LFA-1 is only known to participate in cell-cell adhesion through binding to ICAMs. It is important for efficient entry of lymphocytes into sites of inflammation and lymphoid tissues. LFA-1 is also required for the retention of marginal zone B cells in the splenic marginal zone (67). LFA-1 is also a defining component of the immunological synapse formed by $\mathrm{T}$ cells with antigen presenting cells $(68,69)$. Interestingly, LFA-1 is readily activated for binding to ICAM-1 in monocyte and immature dendritic cells, but become inactive and refractory to activation in mature dendritic cells (70). The reason for this is not clear, but may prevent DC from forming homotypic aggregates that could exclude T cells when ICAM-1 is upregulated during maturation. The low affinity form of LFA-1 binding ICAM-1 with a $\mathrm{K}_{\mathrm{d}}$ of $\sim 1.5 \mathrm{mM}$, whereas the intermediate and high affinity forms binds with $\mathrm{K}_{\mathrm{d}} \mathrm{s}$ of $\sim 15 \mu \mathrm{M}$ and $\sim 150 \mathrm{nM}$, respectively, an up to 10,000 increase in affinity (42). The LFA-1-ICAM-1 interaction is highly dynamic in vivo suggesting that leukocytes likely utilize a mixture of intermediate and high affinity conformations with a continuum of interactions time frames modulated by force dependent effects. The structure of the LFA-1 I-domain in a complex with the first Iglike domain of ICAM-1 has been solved and shows the coordination of the $\mathrm{Mg}^{2+}$ ion with the E34 residue, which is critical for binding (42).

CR3 is expressed on myeloid cells and activated T cells subsets and plays an important role in leukocyte interactions with endothelial cells by binding to a ICAM-1, although at a distinct site from that bound by LFA-1 (64), and it plays a critical role in phagocytosis of particles that are coated with fragments of the third component of complement, including iC3b $(71,72)$. Recently, the crystal structure of the CR3 I-domain bounds to a further breakdown product of $\mathrm{iC} 3 \mathrm{~b}$, called $\mathrm{C} 3 \mathrm{~d}$, has been solved revealing the central interaction of the bound $\mathrm{Mg}^{2+}$ with an aspartic acid in C3d (7). Its also apparent from this structure that CR3 cannot bind C3b due to a steric conflict with the CUB domain, which is partly unfolded in iC $3 b$ (7). In addition to high affinity ligands like ICAM-1 and iC3b/C3d, CR3 also appears to have a multiple low affinity interactions with large recombinant ligands like $\mathrm{iC} 3 \mathrm{~b}$ and its likely this is based on recognition of acidic side chains in denatured/unstructured peptides $(7,73)$.

CR3 deficient macrophages have defects in uptake of Mycobacterium tuberculosis and a significant component of this defect is directly attributable to complement receptor function $(74,75)$. In mouse models of Alzhimer's disease, C1q, C3 and CR3 expressed by microglial cells are required for destruction of synapses early in the disease process (76). This was a particularly interesting study because unlike others that viewed microglia as reacting to plaques, this study suggests a more direct pathogen role. The role of inflammation and complement in neurogeneration is complicated with both protective and pathological roles of complement in different models (77).

CR4 is expressed on dendritic cells, tissue macrophages and effector T cells. High expression of CR4 is use as a marker of dendritic cells for isolation and the CR4 (CD11c) 
promoter has been used to drive expression of fluorescent proteins (78) and the diphtheria toxin receptor for visualization and deletion of dendritic cells, respectively (79). Despite the progress enabled by these tools, there are caveats to exclusive use of CR4 as a marker for DC. Recently, Nussenzweig has generated an alterative set of tools based on Zbtb46 as being a cleaner promoter for the classical DC lineage, fate mapping or deletion (80). CR4 has lower affinity for $\mathrm{iC} 3 \mathrm{~b}$ than $\mathrm{CR} 3$ and does not interact with $\mathrm{C} 3 \mathrm{~d}$, instead binding to the released $\mathrm{C} 3 \mathrm{c}$ fragment (8). $\mathrm{CR} 4$ also has a functionally relevant interaction with ICAM-1, ICAM-2 and VCAM-1 and thus can mediate attachment of cells to inflamed endothelial cells. As discussed for CR3, CR4 also has the capacity to bind many ligands with exposed acidic side chains and it has been proposed that an important function of CR4 is to sense the denatured proteins as a danger signal associated with tissue injury (73). The CR4 (CD11c) knockout mouse has a phenotype of reduced atherosclerosis and autoimmunity $(81,82)$. Interestingly, T cells elicited by immunization of CR4 deficient mice with myelinoligodendrocyte glycoprotein are not encephalogenic in wild type mice. Its not clear if this phenotype is $\mathrm{T}$ cell intrinsic, or if its imparted to the $\mathrm{T}$ cells by defective antigen presentation or microenvironment related defects in myeloid cells. Effector T cells express significant levels of CR3 and CR4 and complement activation, particularly in relation to CD46, has been implicated in $\mathrm{T}$ cell activation (83-85). It seems likely that some of these effects are dependent upon myeloid cells (16) and it will be an interesting to see how our understanding of $\mathrm{T}$ cell vs myeloid functions of these receptors.

The integrin CD11d is the least studied of the $\beta 2$ integrins and has no known complementreceptor function. It is highly expressed in red pulp macrophages and some $\gamma \delta \mathrm{T}$ cell subsets. It has also been shown that $\mathrm{T}$ cell responses to superantigens are reduced in the absence of CD11d (86), similar to results with CR3, although expression of CD11d in T cell seems more restricted than either CR3 or CR4. Antibodies to CD11d have shown promise in enhancing recover of spinal cord and cerebral cortex following traumatic injury (87).

Myeloid cells express a number of other integrin including receptors for fibronectin (a5 $\beta 1$ ), vitronectin ( $a v \beta 3$ ), laminin ( $\alpha 6 \beta 1)$ and collagen ( $\alpha 1$ and $\alpha 2 \beta 1)$. Myeloid cells generally lack expression of the VCAM-1 receptor ( $\alpha 4 \beta 1)$, which renders them more dependent upon $\beta 2$ integrins for extravasation at sites of inflammation. The E-cadherin binding integrin aE $\beta 7$ is a marker for a subset of intestinal lamina propria DC that play important roles in homeostasis with gut microbes (88). Dendritic cells also utilize the integrin a V $\beta 8$ for activation of transforming growth factor- $\beta$, which is critical for maintaining regulatory $T$ cells (40). Surprisingly, DC lacking all of the major integrins including $\alpha \mathrm{V}, \beta 1$ and $\beta 3$ were able to migrate from the skin to the lymph node and localize in the $\mathrm{T}$ cell zones (89). This finding resonates with earlier studies suggesting that amoeboid location can operate by mechanical coupling between cell shape and confining features of the 3D matrix and cellular environment with very low or no adhesion (90).

\section{Immunoglobulin superfamily complement receptors}

Most of the complement regulatory proteins are in the SCR structural family, except VSIG4 (also called CRIg) that competes for binding to C3b with C5 that connects the alternative C3 convertase to terminal complement components. VSIG4 is part of a subfamily of the Ig- 
superfamily with 2 Ig-like domains and a short cytoplasmic domain (10). It is expressed on Kupffer cells and peritoneal macrophages. It is critical for the ability of Kupffer cells to clear iC3b opsonized bacteria from the blood and thus contributes to control infection $(9,91)$. VSIG4 also appears to direct phagocytosed cargo to autophagic compartments that also improve control of intracellular bacteria (92). VSIG4 suppresses complement-mediated injury in arthritis models when administered as an Ig-fusion proteins (93). Recently, VSIG4 has been shown to have direct pattern recognition function in clearance of gram $^{+}$bacteria from the blood (94).

\section{Integrative functions}

Myeloid cells move from the bone marrow to tissue sites via the blood and need to cross endothelial barriers to gain access to tissues. Complement proteins, particularly the anaphylatoxins play an important role, but punctuate processes that depend upon noncomplement adhesion and guidance systems. At sites of inflammation the endothelium becomes modified to increase adhesiveness in a process that can be acute or chronic. There are three key steps that are classically served by three distinct molecular families. Initial adhesion mediated by selectins, rapid activation mediated by chemokine receptors and firm adhesion and motility mediated by integrins $(95,96)$.

The rolling adhesion is mediated by the brief and low valance interaction of selectins to specific glycans that are present in high abundance. The selectins are single chain type I transmembrane glycoproteins that have $\mathrm{N}$-terminal lectin domains. CD62L is critical for leukocyte rolling in secondary lymphoid tissues where is binds sialyl Lewis $\mathrm{X}$ based carbohydrate moieties carried on multiple core proteins of the high endothelial cells. Note that the second described form of Leukocyte adhesion deficiency, LAD2, is based on deficiency in the ability to add fucose sugar chains that are required to make selectin ligands (97). Inflammed endothelial cells rapidly upregulate $\mathrm{CD} 62 \mathrm{P}$ on their surface in response to inflammation due to stored CD62P in Weibel-Palade bodies in the endothelial cells. CD62P bind sialyl lewis-X determinants in the context of the core protein PSGL1, which is also sulfated on tyrosines to form the optimal ligand. In some contexts PSGL1 can be expressed without the appropriate carbohydrate modifications, in which case it does not serve as a functional ligand for CD62P. CD62E is upregulated on endothelial cells by inflammation over a period of hours to further increase adhesion of leukocyte bearing sialyl lewis-X glycans (98).

Once the leukocyte is in transient contact with the endothelial wall an activating signal is needed to induce firm, integrin mediated adhesion or else the leukocyte will detach and resume flowing with the blood until it reaches another capillary bed. The activating signal is generally provided by a "chemoattractant" that is acting in an acute activation mode. Chemokines can be presented by the endothelial cells because they bind to heparan sulfate proteoglycans, but can also be provided by other types of ligands of pertussis toxin sensitive G protein coupled receptors with the requirement that activation is rapid (99). Nonchemokine attractants that can induce arrest of rolling leukocytes includes platelet activating factor and C5a (100). 
Chemokine receptor signals rapidly activate integrins such as LFA-1 and CR3 and induce spreading of the leukocyte on the endothelial surface. Leukocytes then extravasate using either junctional or transcellular routes (101). The junctional route requires disengaging or rearranging multiple junctional adhesion mechanisms of the endothelial cells and can be achieved without or with significant vascular leakage depending upon other signals (102). An alternative mode of interaction between leukocytes and endothelial cells is intravascular scanning, which was first observed in the liver for natural killer T cells (103), but has now been described more widely for the CX3CR $1^{+}$subpopulation of monocytes (104). It is assumed that this is a form of surveillance of the endothelium and endothelial wall as it is also observed in arterioles and large arteries in which the endothelium is not accessible from the tissue.

The behavior of myeloid cells in tissues is characterized by neutrophil swarming in acute responses to sterile tissue injury or microbe driven inflammation. The process can be coordinated by cytokines like IL-1 in the case of Staphylococcal infection or neutrophil apoptosis with release of leukotriene B4 $(105,106)$. Neutrophil movement can be highly directed, but is not integrin dependent. The convergence of neutrophils in foci above a critical cell number leads to formation of integrin dependent cell aggregates. These aggregates are sufficiently forceful to rapidly exclude extracellular matrix fibrils without proteolysis. In vitro studies suggest a hierarchy of signals with endogenous signals taking a back seat to microbial signal like guidance to formylated peptides, that provide direct targeting to the microbe, but this has not been clearly demonstrated in vivo (107). As complement activation takes places on microbial surfaces, which will then be sources of anaphylatoxins $\mathrm{C} 3 \mathrm{a}$ and $\mathrm{C} 5 \mathrm{a}$, it has been found that C5a is dominant of LTB4 in attracting neutrophils, as mentioned above (14). In the context of bacterial infections that are not cleared by neutrophils, $\mathrm{CCR} 2^{+}$monocytes are recruited along with NK cells and eventually effector $\mathrm{T}$ cells (108). $\mathrm{T}$ cell production of cytokines may either guide a response down inappropriate pathway to resolution, but in some situations can lead to inappropriate responses that lead to fatal immunopathology or chronicity $(102,109)$. Intravascular complement activation in LPS primed mice results in fatal shock that depends upon the C5aR (110), but its not clear if complement deposition on the endothelial cells plays a role in leukocyte interactions, or if these interactions are mediated by classical endothelial adhesion molecules like ICAM-1, ICAM-2 and VCAM.

\section{Phagocytic synapses}

Phagocytosis of foreign bodies and microbes is a critical function of myeloid cells. Foreign objects and microbes are likely to become opsonized with complement, natural antibodies and may also have evolutionarily conserved patterns that are directly recognized by pattern recognition receptors on the myeloid cells. Activating FcR and pattern recognition receptors like Dectin-1, which recognizes mannans found in fungal cell walls, signal through tyrosine kinases cascades driven by Src family and Syk family kinases leading to activation of phospholipase C- $\gamma$ (111). While activating FcR has non-covalently associated subunits with immunotyrosine activation motifs (ITAMs) in which a pair of precisely spaced tyrosines are phosphorylated by a Src family kinase and the recruits a Syk family kinase through its two $\mathrm{SH} 2$ domains that in turn targets an adapter to allow PLC- $\gamma$ recruitment. In the case of 
Dectin-1, each receptor has a single tyrosine motif and dimerization of the receptors by mannans creates a functional ITAM. As such, each receptor has a half or hemi-TAM (112). This is the same mode of signaling utilized by the T cell antigen receptors, for which exclusion of large phosphatases CD45 and CD148 is a common feature of the immunological synapse- a specialized junction that facilitates signaling and effector functions $(113,114)$. Dectin-1 mediated phagocytosis of yeast particles has been shown to induce CD45 exclusion as part of the formation of the phagocytic cup- suggesting that a phagocytic synapse may use similar topological strategies (115). This is consistent with the relatively small size of Dectin-1 and its interaction with a relatively flat surface like a yeast cell wall, or experimentally, a latex bead, that together drive CD45 exclusion.

Small receptors like FcR and Dectin-1 generate close contacts that may exclude CD45 and allow local propagation of tyrosine kinase cascades, but it has not been thought that large receptors like integrins or CR1 would be able to mediate such close contacts. It is not clear if $\mathrm{CR} 3$ mediated interactions with $\mathrm{iC} 3 \mathrm{~b}$ or $\mathrm{C} 3 \mathrm{~d}$ on opsonized particles or in combination with FcR would generate similar phagocytic synapses as part of the activation process. A recent study from Grinstein and colleagues suggests that integrins are capable or orchestrating CD45 exclusion in an F-actin dependent manner (116). In this study, a ligand for CR3, fibrinogen, was interspersed on a surface with a pattern of $\mathrm{IgG}$ to locally engage $\mathrm{Fc}$ receptors, which provided activating signals. Rather than simply excluding CD45 from small Fc receptor clusters, a CR3 mediated Arp2/3 complex dependent mechanism excluded CD45 from large areas that extended 1-2 $\mu \mathrm{m}$ from the site of FcR activation (116). The Fc receptor signaling activates WASP that in turn activates the Arp2/3 complex to nucleate branched Factin networks that can generate protrusive forces, apparently capable of CD45 exclusion. It is not clear how the integrins in this setting are linked to the F-actin- but its likely that talin and kindling 3 are involved. It is also of interest to consider if the very large CR1 molecules could similarly become involved in a F-actin dependent close contact process (Figure 3). Each LHR of CR1 could extend $25 \mathrm{~nm}$ based on the electron microscopy structure of C4 binding protein (117). Thus, CR1 could have a total length approaching $100 \mathrm{~nm}$. Even if its is assumed that CR1 would be hinged and flexible, its would likely generate too large an inter-membrane separation when binding to its ligands to exclude CD45 when bound to C3b, which is itself a relatively compact globular proteins with the receptor binding sites very close to the membrane. Evaluating the potential of CR1 mediated interaction with $\mathrm{C} 3 \mathrm{~b}$ on a surface to exclude CD45 in support of local tyrosine kinase cascades will require direct measurements. Such experiments could provide a complementary data set to the one generated by Grinstein's group for integrins. If CR1 is capable of generating similar F-actin dependent close contacts following triggering by a smaller $\mathrm{Fc}$ receptor, then this would place additional constraints on models to explain this phenomenon. Since the function of CR1 and CR3 overlap in many contexts in vitro, it seems plausible that CR1 may in some way access a similar active mechanism for promoting close contacts despite its apparently long reach. The function of this extended CD45 exclusion was not entirely clear, but it was proposed that it allows extension of the phagocytic cup past sparse sites of opsonisation. Such a mechanism may also allow CR3 and CR4 to mediate phagocytosis of $\mathrm{iC} 3 \mathrm{~b}$ coated particles without an FcR signal. 


\section{Complement in $\mathrm{T}$ cell activation}

Complement activation has been proposed to play a role in $\mathrm{T}$ cell activation. C3aR and C5aR mediate one mode of complement dependent activation in T cell priming (16). Kubes has also reported that $\mathrm{CD} 4 \mathrm{~T}$ cells use $\mathrm{C} 5 \mathrm{aR}$ to delayed type hypersensitivity reactions in vivo (118). The complement regulatory protein CD46 mediates a second mechanism $(83,84$, 119). CD46 is a SCR family member with 4 SCR domains, transmembrane domain and a cytoplasmic domain that links to polarity proteins (120). CD46 shares activities with CR1 in that it binds $\mathrm{C} 3 \mathrm{~b}$ and $\mathrm{C} 4 \mathrm{~b}$, and protects host cells from complement mediated damage. Its intriguing that VSIG4, which protects the vascular system from alternative pathway activation by clearing hydrolyzed $\mathrm{C} 3$ from the blood and preventing its association with $\mathrm{C} 5$ (10), is also a negative regulator of $\mathrm{T}$ cell function $(11,92,121,122)$. The high expression of VSIG4 in the liver and peritoneal cavity may help establish a level of immune privilege in these sites (123), although the role of VSIG4 has not been investigated. The receptor for VSIG4 on T cells is not known, but its intriguing to consider that VSIG4 mediated inhibition of complement activation could be related to its ability to inhibit $\mathrm{T}$ cell activation.

\section{Future directions}

The SCR superfamily and integrin family receptors play diverse and indispensible roles in innate immunity including the regulation of complement cascades, leukocyte localization and myeloid cells effector function. The relationship between extension and headpiece conformation is still a matter of debate and is challenging to address. While integrins have been studied extensively with electron microscopy and modern data processing methods (124), most of the electron microscopy studies on complement regulators were carried out earlier. Zhu and colleagues have suggested that LFA-1 may underdo extension and genuflection while bound to ligand with high/intermediate affinity (125). This is significant because the genuflected interaction will bring membranes closer together and may form a better seal. Can large receptors like CR1 participate in such close contact or are their roles more in initial capture of particles, which are then "reeled in" by integrins in an F-actin dependent manner. There are also a number of questions about differential regulation of integrins on myeloid cells; for example, how on dendritic cells LFA-1 is turned off while integrins like $\alpha \mathrm{V} \beta 8$ remain active in regulation of TGF $\beta$ activation. What are the mechanisms for differential regulation of integrins? Recent studies on the regional diversity of macrophages may further add opportunities for tissue specific regulation of such processes (126).

\section{References}

1. Holers VM. Complement and its receptors: new insights into human disease. Annu Rev Immunol. 2014; 32:433-59. DOI: 10.1146/annurev-immunol-032713-120154 [PubMed: 24499275]

2. Merle NS, Church SE, Fremeaux-Bacchi V, Roumenina LT. Complement System Part I - Molecular Mechanisms of Activation and Regulation. Frontiers in immunology. 2015; 6:262.doi: 10.3389/ fimmu.2015.00262 [PubMed: 26082779]

3. Janssen BJ, Huizinga EG, Raaijmakers HC, Roos A, Daha MR, Nilsson-Ekdahl K, et al. Structures of complement component $\mathrm{C} 3$ provide insights into the function and evolution of immunity. Nature. 2005; 437(7058):505-11. Epub 2005/09/24. DOI: 10.1038/nature04005 [PubMed: 16177781] 
4. Hermanowski-Vosatka A, Detmers PA, Gotze O, Silverstein SC, Wright SD. Clustering of ligand on the surface of a particle enhances adhesion to receptor-bearing cells. J Biol Chem. 1988; 263(33): 17822-7. Epub 1988/11/25. [PubMed: 2972724]

5. Rothlein R, Springer TA. Complement receptor type three-dependent degradation of opsonized erythrocytes by mouse macrophages. J Immunol. 1985; 135(4):2668-72. [PubMed: 3897377]

6. Fallman M, Andersson R, Andersson T. Signaling properties of CR3 (CD11b/CD18) and CR1 (CD35) in relation to phagocytosis of complement-opsonized particles. J Immunol. 1993; 151(1): 330-8. [PubMed: 8326130]

7. Bajic G, Yatime L, Sim RB, Vorup-Jensen T, Andersen GR. Structural insight on the recognition of surface-bound opsonins by the integrin I domain of complement receptor 3. Proc Natl Acad Sci U S A. 2013; 110(41):16426-31. DOI: 10.1073/pnas.1311261110 [PubMed: 24065820]

8. Chen X, Yu Y, Mi LZ, Walz T, Springer TA. Molecular basis for complement recognition by integrin alphaXbeta2. Proc Natl Acad Sci U S A. 2012; 109(12):4586-91. Epub 2012/03/07. DOI: 10.1073/ pnas.1202051109 [PubMed: 22393018]

9. Gorgani NN, He JQ, Katschke KJ Jr, Helmy KY, Xi H, Steffek M, et al. Complement receptor of the Ig superfamily enhances complement-mediated phagocytosis in a subpopulation of tissue resident macrophages. J Immunol. 2008; 181(11):7902-8. [PubMed: 19017980]

10. Wiesmann C, Katschke KJ, Yin J, Helmy KY, Steffek M, Fairbrother WJ, et al. Structure of C3b in complex with CRIg gives insights into regulation of complement activation. Nature. 2006; 444(7116):217-20. Epub 2006/10/20. DOI: 10.1038/nature05263 [PubMed: 17051150]

11. Vogt L, Schmitz N, Kurrer MO, Bauer M, Hinton HI, Behnke S, et al. VSIG4, a B7 family-related protein, is a negative regulator of $\mathrm{T}$ cell activation. J Clin Invest. 2006; 116(10):2817-26. DOI: 10.1172/JCI25673 [PubMed: 17016562]

12. Bajic G, Yatime L, Klos A, Andersen GR. Human C3a and C3a desArg anaphylatoxins have conserved structures, in contrast to C5a and C5a desArg. Protein Sci. 2013; 22(2):204-12. DOI: 10.1002/pro.2200 [PubMed: 23184394]

13. Skokowa J, Ali SR, Felda O, Kumar V, Konrad S, Shushakova N, et al. Macrophages induce the inflammatory response in the pulmonary Arthus reaction through $\mathrm{G}$ alpha i2 activation that controls C5aR and Fc receptor cooperation. J Immunol. 2005; 174(5):3041-50. [PubMed: 15728518]

14. Heit B, Tavener S, Raharjo E, Kubes P. An intracellular signaling hierarchy determines direction of migration in opposing chemotactic gradients. J Cell Biol. 2002; 159(1):91-102. Epub 2002/10/09. jcb.200202114 [pii]. DOI: 10.1083/jcb.200202114 [PubMed: 12370241]

15. Flaherty P, Radhakrishnan ML, Dinh T, Rebres RA, Roach TI, Jordan MI, et al. A dual receptor crosstalk model of G-protein-coupled signal transduction. PLoS Comput Biol. 2008; 4(9):e1000185.doi: 10.1371/journal.pcbi.1000185 [PubMed: 18818727]

16. Strainic MG, Liu J, Huang D, An F, Lalli PN, Muqim N, et al. Locally produced complement fragments $\mathrm{C} 5 \mathrm{a}$ and $\mathrm{C} 3 \mathrm{a}$ provide both costimulatory and survival signals to naive CD4+ T cells. Immunity. 2008; 28(3):425-35. DOI: 10.1016/j.immuni.2008.02.001 [PubMed: 18328742]

17. Senior RM, Griffin GL, Perez HD, Webster RO. Human C5a and C5a des Arg exhibit chemotactic activity for fibroblasts. J Immunol. 1988; 141(10):3570-4. [PubMed: 3183381]

18. Bamberg CE, Mackay CR, Lee H, Zahra D, Jackson J, Lim YS, et al. The C5a receptor (C5aR) C5L2 is a modulator of C5aR-mediated signal transduction. J Biol Chem. 2010; 285(10):7633-44. DOI: 10.1074/jbc.M109.092106 [PubMed: 20044484]

19. Venkiteswaran G, Lewellis SW, Wang J, Reynolds E, Nicholson C, Knaut H. Generation and dynamics of an endogenous, self-generated signaling gradient across a migrating tissue. Cell. 2013; 155(3):674-87. DOI: 10.1016/j.cell.2013.09.046 [PubMed: 24119842]

20. Humbles AA, Lu B, Nilsson CA, Lilly C, Israel E, Fujiwara Y, et al. A role for the C3a anaphylatoxin receptor in the effector phase of asthma. Nature. 2000; 406(6799):998-1001. DOI: 10.1038/35023175 [PubMed: 10984054]

21. Hopken UE, Lu B, Gerard NP, Gerard C. The C5a chemoattractant receptor mediates mucosal defence to infection. Nature. 1996; 383(6595):86-9. DOI: 10.1038/383086a0 [PubMed: 8779720]

22. Banda NK, Hyatt S, Antonioli AH, White JT, Glogowska M, Takahashi K, et al. Role of C3a receptors, $\mathrm{C} 5 \mathrm{a}$ receptors, and complement protein $\mathrm{C} 6$ deficiency in collagen antibody-induced 
arthritis in mice. J Immunol. 2012; 188(3):1469-78. DOI: 10.4049/jimmunol.1102310 [PubMed: 22205026]

23. Andersson C, Wenander CS, Usher PA, Hebsgaard JB, Sondergaard BC, Rono B, et al. Rapid-onset clinical and mechanistic effects of anti-C5aR treatment in the mouse collagen-induced arthritis model. Clin Exp Immunol. 2014; 177(1):219-33. DOI: 10.1111/cei.12338 [PubMed: 24665841]

24. Vergunst CE, Gerlag DM, Dinant H, Schulz L, Vinkenoog M, Smeets TJ, et al. Blocking the receptor for $\mathrm{C} 5 \mathrm{a}$ in patients with rheumatoid arthritis does not reduce synovial inflammation. Rheumatology (Oxford). 2007; 46(12):1773-8. DOI: 10.1093/rheumatology/kem222 [PubMed: 17965442]

25. Jacobson AC, Weis JH. Comparative functional evolution of human and mouse CR1 and CR2. J Immunol. 2008; 181(5):2953-9. [PubMed: 18713965]

26. Donius LR, Handy JM, Weis JJ, Weis JH. Optimal germinal center B cell activation and Tdependent antibody responses require expression of the mouse complement receptor Cr1. J Immunol. 2013; 191(1):434-47. DOI: 10.4049/jimmunol.1203176 [PubMed: 23733878]

27. Hourcade D, Miesner DR, Bee C, Zeldes W, Atkinson JP. Duplication and divergence of the amino-terminal coding region of the complement receptor 1 (CR1) gene. An example of concerted (horizontal) evolution within a gene. J Biol Chem. 1990; 265(2):974-80. [PubMed: 2295627]

28. Java A, Liszewski MK, Hourcade DE, Zhang F, Atkinson JP. Role of complement receptor 1 (CR1; CD35) on epithelial cells: A model for understanding complement-mediated damage in the kidney. Mol Immunol. 2015; 67(2 Pt B):584-95. DOI: 10.1016/j.molimm.2015.07.016 [PubMed: 26260209]

29. Schramm EC, Roumenina LT, Rybkine T, Chauvet S, Vieira-Martins P, Hue C, et al. Mapping interactions between complement $\mathrm{C} 3$ and regulators using mutations in atypical hemolytic uremic syndrome. Blood. 2015; 125(15):2359-69. DOI: 10.1182/blood-2014-10-609073 [PubMed: 25608561]

30. Molina H, Holers VM, Li B, Fung Y, Mariathasan S, Goellner J, et al. Markedly impaired humoral immune response in mice deficient in complement receptors 1 and 2. Proc Natl Acad Sci U S A. 1996; 93(8):3357-61. [PubMed: 8622941]

31. Repik A, Pincus SE, Ghiran I, Nicholson-Weller A, Asher DR, Cerny AM, et al. A transgenic mouse model for studying the clearance of blood-borne pathogens via human complement receptor 1 (CR1). Clin Exp Immunol. 2005; 140(2):230-40. DOI: 10.1111/j.1365-2249.2005.02764.x [PubMed: 15807846]

32. Newman SL, Becker S, Halme J. Phagocytosis by receptors for C3b (CR1), iC3b (CR3), and IgG (Fc) on human peritoneal macrophages. J Leukoc Biol. 1985; 38(2):267-78. [PubMed: 2993460]

33. Holers VM, Kinoshita T, Molina H. The evolution of mouse and human complement C3-binding proteins: divergence of form but conservation of function. Immunol Today. 1992; 13(6):231-6. [PubMed: 1378280]

34. Paccaud JP, Carpentier JL, Schifferli JA. Difference in the clustering of complement receptor type 1 (CR1) on polymorphonuclear leukocytes and erythrocytes: effect on immune adherence. Eur J Immunol. 1990; 20(2):283-9. DOI: 10.1002/eji.1830200209 [PubMed: 2138082]

35. Ghiran I, Glodek AM, Weaver G, Klickstein LB, Nicholson-Weller A. Ligation of erythrocyte CR1 induces its clustering in complex with scaffolding protein FAP-1. Blood. 2008; 112(8):3465-73. DOI: 10.1182/blood-2008-04-151845 [PubMed: 18684861]

36. Springer TA, Dustin ML. Integrin inside-out signaling and the immunological synapse. Curr Opin Cell Biol. 2012; 24(1):107-15. Epub 2011/12/02. DOI: 10.1016/j.ceb.2011.10.004 [PubMed: 22129583]

37. Vogel V, Sheetz MP. Cell fate regulation by coupling mechanical cycles to biochemical signaling pathways. Curr Opin Cell Biol. 2009; 21(1):38-46. Epub 2009/02/17. DOI: 10.1016/j.ceb. 2009.01.002 [PubMed: 19217273]

38. Sanchez-Madrid F, Nagy JA, Robbins E, Simon P, Springer TA. A human leukocyte differentiation antigen family with distinct alpha-subunits and a common beta-subunit: the lymphocyte functionassociated antigen (LFA-1), the C3bi complement receptor (OKM1/Mac-1), and the p150,95 molecule. J Exp Med. 1983; 158(6):1785-803. Epub 1983/12/01. [PubMed: 6196430] 
39. Anderson DC, Springer TA. Leukocyte adhesion deficiency: An inherited defect in the Mac-1, LFA-1, and p150,95 glycoproteins. Ann Rev Med. 1987; 38:175-94. [PubMed: 3555290]

40. Worthington JJ, Kelly A, Smedley C, Bauche D, Campbell S, Marie JC, et al. Integrin alphavbeta8Mediated TGF-beta Activation by Effector Regulatory T Cells Is Essential for Suppression of TCell-Mediated Inflammation. Immunity. 2015; 42(5):903-15. DOI: 10.1016/j.immuni.2015.04.012 [PubMed: 25979421]

41. Xiong JP, Stehle T, Zhang R, Joachimiak A, Frech M, Goodman SL, et al. Crystal structure of the extracellular segment of integrin alpha Vbeta3 in complex with an Arg-Gly-Asp ligand. Science. 2002; 296(5565):151-5. [PubMed: 11884718]

42. Shimaoka M, Xiao T, Liu JH, Yang Y, Dong Y, Jun CD, et al. Structures of the alpha L I domain and its complex with ICAM-1 reveal a shape-shifting pathway for integrin regulation. Cell. 2003; 112(1):99-111. [PubMed: 12526797]

43. Choi WS, Rice WJ, Stokes DL, Coller BS. Three-dimensional reconstruction of intact human integrin alphallbbeta3: new implications for activation-dependent ligand binding. Blood. 2013; 122(26):4165-71. DOI: 10.1182/blood-2013-04-499194 [PubMed: 24136164]

44. Garcia-Alvarez B, de Pereda JM, Calderwood DA, Ulmer TS, Critchley D, Campbell ID, et al. Structural determinants of integrin recognition by talin. Mol Cell. 2003; 11(1):49-58. [PubMed: 12535520]

45. Cavalcanti-Adam EA, Volberg T, Micoulet A, Kessler H, Geiger B, Spatz JP. Cell spreading and focal adhesion dynamics are regulated by spacing of integrin ligands. Biophys J. 2007; 92(8): 2964-74. Epub 2007/02/06. doi: S0006-3495(07)71099-8 [pii]. DOI: 10.1529/biophysj. 106.089730 [PubMed: 17277192]

46. Kanchanawong P, Shtengel G, Pasapera AM, Ramko EB, Davidson MW, Hess HF, et al. Nanoscale architecture of integrin-based cell adhesions. Nature. 2010; 468(7323):580-4. Epub 2010/11/26. doi: nature09621 [pii]. DOI: 10.1038/nature09621 [PubMed: 21107430]

47. Kupfer A, Singer SJ. The specific interaction of helper T cells and antigen-presenting B cells. IV. Membrane and cytoskeletal reorganizations in the bound $\mathrm{T}$ cell as a function of antigen dose. $\mathrm{J}$ Exp Med. 1989; 170(5):1697-713. [PubMed: 2530300]

48. Lim J, Wiedemann A, Tzircotis G, Monkley SJ, Critchley DR, Caron E. An essential role for talin during alpha(M)beta(2)-mediated phagocytosis. Mol Biol Cell. 2007; 18(3):976-85. DOI: 10.1091/mbc.E06-09-0813 [PubMed: 17202407]

49. Yao M, Goult BT, Chen H, Cong P, Sheetz MP, Yan J. Mechanical activation of vinculin binding to talin locks talin in an unfolded conformation. Scientific reports. 2014; 4:4610.doi: 10.1038/ srep04610 [PubMed: 24714394]

50. Le Trong I, Aprikian P, Kidd BA, Forero-Shelton M, Tchesnokova V, Rajagopal P, et al. Structural basis for mechanical force regulation of the adhesin FimH via finger trap-like beta sheet twisting. Cell. 2010; 141(4):645-55. DOI: 10.1016/j.cell.2010.03.038 [PubMed: 20478255]

51. Baorto DM, Gao Z, Malaviya R, Dustin ML, van der Merwe A, Lublin DM, et al. Survival of FimH-expressing enterobacteria in macrophages relies on glycolipid traffic. Nature. 1997; 389(6651):636-9. [PubMed: 9335508]

52. Hynes RO. Integrins: a family of cell surface receptors. Cell. 1987; 48(4):549-54. [PubMed: 3028640]

53. Hemler ME, Sanchez-Madrid F, Flotte TJ, Krensky AM, Burakoff SJ, Bhan AK, et al. Glycoproteins of 210,000 and 130,000 m.w. on activated T cells: cell distribution and antigenic relation to components on resting cells and T cell lines. J Immunol. 1984; 132(6):3011-8. Epub 1984/06/01. [PubMed: 6327814]

54. Elices MJ, Osborn L, Takada Y, Crouse C, Luhowskyj S, Hemler ME, et al. VCAM-1 on activated endothelium interacts with the leukocyte integrin VLA-4 at a site distinct from the VLA-4/ fibronectin binding site. Cell. 1990; 60(4):577-84. [PubMed: 1689216]

55. Springer TA, Dustin ML. Integrin inside-out signaling and the immunological synapse. Curr Opin Cell Biol. 2011; Epub 2011/12/02. doi: 10.1016/j.ceb.2011.10.004

56. Nishida N, Xie C, Shimaoka M, Cheng Y, Walz T, Springer TA. Activation of leukocyte beta2 integrins by conversion from bent to extended conformations. Immunity. 2006; 25(4):583-94. [PubMed: 17045822] 
57. Stewart MP, Cabanas C, Hogg N. T cell adhesion to intercellular adhesion molecule-1 (ICAM-1) is controlled by cell spreading and the activation of integrin LFA-1. J Immunol. 1996; 156(5):18107. [PubMed: 8596031]

58. Comrie WA, Babich A, Burkhardt JK. F-actin flow drives affinity maturation and spatial organization of LFA-1 at the immunological synapse. J Cell Biol. 2015; 208(4):475-91. DOI: 10.1083/jcb.201406121 [PubMed: 25666810]

59. Kishimoto TK, Hollander N, Roberts TM, Anderson DC, Springer TA. Heterogeneous mutations in the beta subunit common to the LFA-1, Mac-1, and p150,95 glycoproteins cause leukocyte adhesion deficiency. Cell. 1987; 50(2):193-202. Epub 1987/07/17. doi: 0092-8674(87)90215-7 [pii]. [PubMed: 3594570]

60. Thomas C, Le Deist F, Cavazzana-Calvo M, Benkerrou M, Haddad E, Blanche S, et al. Results of allogeneic bone marrow transplantation in patients with leukocyte adhesion deficiency. Blood. 1995; 86(4):1629-35. [PubMed: 7632973]

61. Manevich-Mendelson E, Feigelson SW, Pasvolsky R, Aker M, Grabovsky V, Shulman Z, et al. Loss of Kindlin-3 in LAD-III eliminates LFA-1 but not VLA-4 adhesiveness developed under shear flow conditions. Blood. 2009; 114(11):2344-53. Epub 2009/07/21. doi: blood-2009-04-218636 [pii]. DOI: 10.1182/blood-2009-04-218636 [PubMed: 19617577]

62. Xue ZH, Feng C, Liu WL, Tan SM. A role of kindlin-3 in integrin alphaMbeta2 outside-in signaling and the Syk-Vav1-Rac1/Cdc42 signaling axis. PLoS One. 2013; 8(2):e56911.doi: 10.1371/journal.pone.0056911 [PubMed: 23437269]

63. Diamond MS, Staunton DE, de Fougerolles AR, Stacker SA, Garcia-Aguilar J, Hibbs ML, et al. ICAM-1 (CD54): a counter-receptor for Mac-1 (CD11b/CD18). J Cell Biol. 1990; 111(6 Pt 2): 3129-39. [PubMed: 1980124]

64. Diamond MS, Staunton DE, Marlin SD, Springer TA. Binding of the integrin Mac-1 (CD11b/ CD18) to the third immunoglobulin-like domain of ICAM-1 (CD54) and its regulation by glycosylation. Cell. 1991; 65(6):961-71. [PubMed: 1675157]

65. Dustin ML, Rothlein R, Bhan AK, Dinarello CA, Springer TA. Induction by IL 1 and interferongamma: tissue distribution, biochemistry, and function of a natural adherence molecule (ICAM-1). J Immunol. 1986; 137(1):245-54. Epub 1986/07/01. [PubMed: 3086451]

66. Staunton DE, Dustin ML, Springer TA. Functional cloning of ICAM-2, a cell adhesion ligand for LFA-1 homologous to ICAM-1. Nature. 1989; 339(6219):61-4. [PubMed: 2497351]

67. Lu TT, Cyster JG. Integrin-mediated long-term B cell retention in the splenic marginal zone. Science. 2002; 297(5580):409-12. DOI: 10.1126/science.1071632 [PubMed: 12130787]

68. Grakoui A, Bromley SK, Sumen C, Davis MM, Shaw AS, Allen PM, et al. The immunological synapse: a molecular machine controlling T cell activation. Science. 1999; 285(5425):221-7. [PubMed: 10398592]

69. Scholer A, Hugues S, Boissonnas A, Fetler L, Amigorena S. Intercellular adhesion molecule-1dependent stable interactions between T cells and dendritic cells determine CD8+ T cell memory. Immunity. 2008; 28(2):258-70. Epub 2008/02/16. doi: S1074-7613(08)00036-8 [pii]. DOI: 10.1016/j.immuni.2007.12.016 [PubMed: 18275834]

70. Cambi A, Joosten B, Koopman M, de Lange F, Beeren I, Torensma R, et al. Organization of the Integrin LFA-1 in Nanoclusters Regulates Its Activity. Mol Biol Cell. 2006; 17(10):4270-81. [PubMed: 16855029]

71. Wright SD, Rao PE, Van Voorhis WC, Craigmyle LS, Iida K, Talle MA, et al. Identification of the C3bi receptor of human monocytes and macrophages by using monoclonal antibodies. Proc Natl Acad Sci U S A. 1983; 80(18):5699-703. Epub 1983/09/01. [PubMed: 6225125]

72. Wright SD, Silverstein SC. Receptors for C3b and C3bi promote phagocytosis but not the release of toxic oxygen from human phagocytes. J Exp Med. 1983; 158(6):2016-23. Epub 1983/12/01. [PubMed: 6227677]

73. Vorup-Jensen T, Carman CV, Shimaoka M, Schuck P, Svitel J, Springer TA. Exposure of acidic residues as a danger signal for recognition of fibrinogen and other macromolecules by integrin alphaXbeta2. Proc Natl Acad Sci U S A. 2005; 102(5):1614-9. [PubMed: 15665082]

74. Melo MD, Catchpole IR, Haggar G, Stokes RW. Utilization of CD11b knockout mice to characterize the role of complement receptor 3 (CR3, CD11b/CD18) in the growth of 
Mycobacterium tuberculosis in macrophages. Cell Immunol. 2000; 205(1):13-23. DOI: 10.1006/ cimm.2000.1710 [PubMed: 11078603]

75. Rooyakkers AW, Stokes RW. Absence of complement receptor 3 results in reduced binding and ingestion of Mycobacterium tuberculosis but has no significant effect on the induction of reactive oxygen and nitrogen intermediates or on the survival of the bacteria in resident and interferongamma activated macrophages. Microb Pathog. 2005; 39(3):57-67. DOI: 10.1016/j.micpath. 2005.05.001 [PubMed: 16084683]

76. Hong S, Beja-Glasser VF, Nfonoyim BM, Frouin A, Li S, Ramakrishnan S, et al. Complement and microglia mediate early synapse loss in Alzheimer mouse models. Science. 2016; 352(6286):7126. DOI: 10.1126/science.aad8373 [PubMed: 27033548]

77. Wyss-Coray T, Rogers J. Inflammation in Alzheimer disease-a brief review of the basic science and clinical literature. Cold Spring Harb Perspect Med. 2012; 2(1) a006346. doi: 10.1101/ cshperspect.a006346

78. Lindquist RL, Shakhar G, Dudziak D, Wardemann H, Eisenreich T, Dustin ML, et al. Visualizing dendritic cell networks in vivo. Nat Immunol. 2004; 5(12):1243-50. [PubMed: 15543150]

79. Jung S, Unutmaz D, Wong P, Sano G, De los Santos K, Sparwasser T, et al. In vivo depletion of $\mathrm{CD} 11 \mathrm{c}(+)$ dendritic cells abrogates priming of CD8(+) T cells by exogenous cell-associated antigens. Immunity. 2002; 17(2):211-20. [PubMed: 12196292]

80. Meredith MM, Liu K, Darrasse-Jeze G, Kamphorst AO, Schreiber HA, Guermonprez P, et al. Expression of the zinc finger transcription factor zDC (Zbtb46, Btbd4) defines the classical dendritic cell lineage. J Exp Med. 2012; 209(6):1153-65. DOI: 10.1084/jem.20112675 [PubMed: 22615130]

81. Bullard DC, Hu X, Adams JE, Schoeb TR, Barnum SR. p150/95 (CD11c/CD18) expression is required for the development of experimental autoimmune encephalomyelitis. Am J Pathol. 2007; 170(6):2001-8. DOI: 10.2353/ajpath.2007.061016 [PubMed: 17525267]

82. Wu H, Gower RM, Wang H, Perrard XY, Ma R, Bullard DC, et al. Functional role of CD11c+ monocytes in atherogenesis associated with hypercholesterolemia. Circulation. 2009; 119(20): 2708-17. DOI: 10.1161/CIRCULATIONAHA.108.823740 [PubMed: 19433759]

83. Astier A, Trescol-Biemont MC, Azocar O, Lamouille B, Rabourdin-Combe C. Cutting edge: CD46, a new costimulatory molecule for T cells, that induces p120CBL and LAT phosphorylation. J Immunol. 2000; 164(12):6091-5. [PubMed: 10843656]

84. Kemper C, Chan AC, Green JM, Brett KA, Murphy KM, Atkinson JP. Activation of human CD4+ cells with CD3 and CD46 induces a T-regulatory cell 1 phenotype. Nature. 2003; 421(6921):38892. DOI: 10.1038/nature01315 [PubMed: 12540904]

85. Ghannam A, Fauquert JL, Thomas C, Kemper C, Drouet C. Human complement C3 deficiency: Th1 induction requires T cell-derived complement C3a and CD46 activation. Mol Immunol. 2014; 58(1):98-107. DOI: 10.1016/j.molimm.2013.11.010 [PubMed: 24321396]

86. Wu H, Rodgers JR, Perrard XY, Perrard JL, Prince JE, Abe Y, et al. Deficiency of CD11b or $\mathrm{CD} 11 \mathrm{~d}$ results in reduced staphylococcal enterotoxin-induced $\mathrm{T}$ cell response and $\mathrm{T}$ cell phenotypic changes. J Immunol. 2004; 173(1):297-306. [PubMed: 15210787]

87. Geremia NM, Bao F, Rosenzweig TE, Hryciw T, Weaver L, Dekaban GA, et al. CD11d Antibody Treatment Improves Recovery in Spinal Cord-Injured Mice. J Neurotrauma. 2012; 29(3):539-50. DOI: 10.1089/neu.2011.1976 [PubMed: 22044160]

88. Arnold IC, Mathisen S, Schulthess J, Danne C, Hegazy AN, Powrie F. CD11c monocyte/ macrophages promote chronic Helicobacter hepaticus-induced intestinal inflammation through the production of IL-23. Mucosal Immunol. 2015; doi: 10.1038/mi.2015.65

89. Lammermann T, Bader BL, Monkley SJ, Worbs T, Wedlich-Soldner R, Hirsch K, et al. Rapid leukocyte migration by integrin-independent flowing and squeezing. Nature. 2008; 453(7191):515. Epub 2008/05/03. doi: nature06887 [pii]. DOI: 10.1038/nature06887 [PubMed: 18451854]

90. Haston WS, Shields JM. Contraction waves in lymphocyte locomotion. J Cell Sci. 1984; 68:22741. [PubMed: 6149228]

91. Helmy KY, Katschke KJ Jr, Gorgani NN, Kljavin NM, Elliott JM, Diehl L, et al. CRIg: a macrophage complement receptor required for phagocytosis of circulating pathogens. Cell. 2006; 124(5):915-27. DOI: 10.1016/j.cell.2005.12.039 [PubMed: 16530040] 
92. Kim KH, Choi BK, Kim YH, Han C, Oh HS, Lee DG, et al. Extracellular stimulation of VSIG4/ complement receptor Ig suppresses intracellular bacterial infection by inducing autophagy. Autophagy. 2016; 0. doi: 10.1080/15548627.2016.1196314

93. Katschke KJ Jr, Helmy KY, Steffek M, Xi H, Yin J, Lee WP, et al. A novel inhibitor of the alternative pathway of complement reverses inflammation and bone destruction in experimental arthritis. J Exp Med. 2007; 204(6):1319-25. DOI: 10.1084/jem.20070432 [PubMed: 17548523]

94. Zeng Z, Surewaard BG, Wong CH, Geoghegan JA, Jenne CN, Kubes P. CRIg Functions as a Macrophage Pattern Recognition Receptor to Directly Bind and Capture Blood-Borne GramPositive Bacteria. Cell Host Microbe. 2016; 20(1):99-106. DOI: 10.1016/j.chom.2016.06.002 [PubMed: 27345697]

95. von Andrian UH, Chambers JD, McEvoy LM, Bargatze RF, Arfors KE, Butcher EC. Two-step model of leukocyte-endothelial cell interaction in inflammation: distinct roles for LECAM-1 and the leukocyte beta 2 integrins in vivo. Proc Natl Acad Sci U S A. 1991; 88(17):7538-42. [PubMed: 1715568]

96. Lawrence MB, Springer TA. Leukocytes roll on a selectin at physiologic flow rates: distinction from and prerequisite for adhesion through integrins. Cell. 1991; 65(5):859-73. [PubMed: 1710173]

97. Wild MK, Luhn K, Marquardt T, Vestweber D. Leukocyte adhesion deficiency II: therapy and genetic defect. Cells Tissues Organs. 2002; 172(3):161-73. [PubMed: 12476046]

98. Pober JS, Bevilacqua MP, Mendrick DL, Lapierre LA, Fiers W, Gimbrone MA Jr. Two distinct monokines, interleukin 1 and tumor necrosis factor, each independently induce biosynthesis and transient expression of the same antigen on the surface of cultured human vascular endothelial cells. J Immunol. 1986; 136(5):1680-7. [PubMed: 3485132]

99. Shamri R, Grabovsky V, Gauguet JM, Feigelson S, Manevich E, Kolanus W, et al. Lymphocyte arrest requires instantaneous induction of an extended LFA-1 conformation mediated by endothelium-bound chemokines. Nat Immunol. 2005; 6(5):497-506. [PubMed: 15834409]

100. Chan JR, Hyduk SJ, Cybulsky MI. Chemoattractants induce a rapid and transient upregulation of monocyte alpha4 integrin affinity for vascular cell adhesion molecule 1 which mediates arrest: an early step in the process of emigration. J Exp Med. 2001; 193(10):1149-58. [PubMed: 11369786]

101. Carman CV, Sage PT, Sciuto TE, de la Fuente MA, Geha RS, Ochs HD, et al. Transcellular diapedesis is initiated by invasive podosomes. Immunity. 2007; 26(6):784-97. [PubMed: 17570692]

102. Kim JV, Kang SS, Dustin ML, McGavern DB. Myelomonocytic cell recruitment causes fatal CNS vascular injury during acute viral meningitis. Nature. 2009; 457(7226):191-5. Epub 2008/11/18. DOI: 10.1038/nature07591 [PubMed: 19011611]

103. Geissmann F, Cameron TO, Sidobre S, Manlongat N, Kronenberg M, Briskin MJ, et al. Intravascular immune surveillance by CXCR6+ NKT cells patrolling liver sinusoids. PLoS Biol. 2005; 3(4):e113. [PubMed: 15799695]

104. Carlin LM, Stamatiades EG, Auffray C, Hanna RN, Glover L, Vizcay-Barrena G, et al. Nr4a1dependent Ly6C(low) monocytes monitor endothelial cells and orchestrate their disposal. Cell. 2013; 153(2):362-75. Epub 2013/04/16. DOI: 10.1016/j.cell.2013.03.010 [PubMed: 23582326]

105. Liese J, Rooijakkers SH, van Strijp JA, Novick RP, Dustin ML. Intravital two-photon microscopy of host-pathogen interactions in a mouse model of Staphylococcus aureus skin abscess formation. Cell Microbiol. 2013; 15(6):891-909. Epub 2012/12/12. DOI: 10.1111/cmi.12085 [PubMed: 23217115]

106. Lammermann T, Afonso PV, Angermann BR, Wang JM, Kastenmuller W, Parent CA, et al. Neutrophil swarms require LTB4 and integrins at sites of cell death in vivo. Nature. 2013; 498(7454):371-5. Epub 2013/05/28. DOI: 10.1038/nature12175 [PubMed: 23708969]

107. Foxman EF, Campbell JJ, Butcher EC. Multistep navigation and the combinatorial control of leukocyte chemotaxis. J Cell Biol. 1997; 139(5):1349-60. Epub 1998/01/07. [PubMed: 9382879]

108. Waite JC, Leiner I, Lauer P, Rae CS, Barbet G, Zheng H, et al. Dynamic imaging of the effector immune response to listeria infection in vivo. PLoS Pathog. 2011; 7(3):e1001326. Epub 2011/04/02. doi: 10.1371/journal.ppat.1001326 [PubMed: 21455492] 
109. Zinselmeyer BH, Heydari S, Sacristan C, Nayak D, Cammer M, Herz J, et al. PD-1 promotes immune exhaustion by inducing antiviral T cell motility paralysis. J Exp Med. 2013; 210(4):75774. Epub 2013/03/27. DOI: 10.1084/jem.20121416 [PubMed: 23530125]

110. Mizuno M, Nishikawa K, Okada N, Matsuo S, Ito K, Okada H. Inhibition of a membrane complement regulatory protein by a monoclonal antibody induces acute lethal shock in rats primed with lipopolysaccharide. J Immunol. 1999; 162(9):5477-82. [PubMed: 10228027]

111. Tohyama Y, Yamamura H. Protein tyrosine kinase, syk: a key player in phagocytic cells. J Biochem. 2009; 145(3):267-73. Epub 2009/01/07. DOI: 10.1093/jb/mvp001 [PubMed: 19124456]

112. Rogers NC, Slack EC, Edwards AD, Nolte MA, Schulz O, Schweighoffer E, et al. Syk-dependent cytokine induction by Dectin-1 reveals a novel pattern recognition pathway for $\mathrm{C}$ type lectins. Immunity. 2005; 22(4):507-17. DOI: 10.1016/j.immuni.2005.03.004 [PubMed: 15845454]

113. Varma R, Campi G, Yokosuka T, Saito T, Dustin ML. T cell receptor-proximal signals are sustained in peripheral microclusters and terminated in the central supramolecular activation cluster. Immunity. 2006; 25(1):117-27. [PubMed: 16860761]

114. Chang VT, Fernandes RA, Ganzinger KA, Lee SF, Siebold C, McColl J, et al. Initiation of T cell signaling by CD45 segregation at 'close contacts'. Nat Immunol. 2016; 17(5):574-82. DOI: 10.1038/ni.3392 [PubMed: 26998761]

115. Goodridge HS, Simmons RM, Underhill DM. Dectin-1 stimulation by Candida albicans yeast or zymosan triggers NFAT activation in macrophages and dendritic cells. J Immunol. 2007; 178(5): 3107-15. Epub 2007/02/22. doi: 178/5/3107 [pii]. [PubMed: 17312158]

116. Freeman SA, Goyette J, Furuya W, Woods EC, Bertozzi CR, Bergmeier W, et al. Integrins Form an Expanding Diffusional Barrier that Coordinates Phagocytosis. Cell. 2016; 164(1-2):128-40. DOI: 10.1016/j.cell.2015.11.048 [PubMed: 26771488]

117. Dahlback B, Smith CA, Muller-Eberhard HJ. Visualization of human C4b-binding protein and its complexes with vitamin K-dependent protein S and complement protein C4b. Proc Natl Acad Sci U S A. 1983; 80(11):3461-5. [PubMed: 6222381]

118. Norman MU, Hulliger S, Colarusso P, Kubes P. Multichannel fluorescence spinning disk microscopy reveals early endogenous CD4 T cell recruitment in contact sensitivity via complement. J Immunol. 2008; 180(1):510-21. [PubMed: 18097053]

119. Kolev M, Dimeloe S, Le Friec G, Navarini A, Arbore G, Povoleri GA, et al. Complement Regulates Nutrient Influx and Metabolic Reprogramming during Th1 Cell Responses. Immunity. 2015; 42(6):1033-47. DOI: 10.1016/j.immuni.2015.05.024 [PubMed: 26084023]

120. Oliaro J, Pasam A, Waterhouse NJ, Browne KA, Ludford-Menting MJ, Trapani JA, et al. Ligation of the cell surface receptor, CD46, alters T cell polarity and response to antigen presentation. Proc Natl Acad Sci U S A. 2006; 103(49):18685-90. DOI: 10.1073/pnas.0602458103 [PubMed: 17116876]

121. Jung K, Seo SK, Choi I. Endogenous VSIG4 negatively regulates the helper T cell-mediated antibody response. Immunol Lett. 2015; 165(2):78-83. DOI: 10.1016/j.imlet.2015.04.004 [PubMed: 25929804]

122. Li Y, Wang YQ, Wang DH, Hou WP, Zhang Y, Li M, et al. Costimulatory molecule VSIG4 exclusively expressed on macrophages alleviates renal tubulointerstitial injury in VSIG4 KO mice. J Nephrol. 2014; 27(1):29-36. DOI: 10.1007/s40620-013-0022-3 [PubMed: 24424721]

123. Fuller MJ, Callendret B, Zhu B, Freeman GJ, Hasselschwert DL, Satterfield W, et al. Immunotherapy of chronic hepatitis $\mathrm{C}$ virus infection with antibodies against programmed cell death-1 (PD-1). Proc Natl Acad Sci U S A. 2013; 110(37):15001-6. Epub 2013/08/28. DOI: 10.1073/pnas.1312772110 [PubMed: 23980172]

124. Takagi J, Petre BM, Walz T, Springer TA. Global conformational rearrangements in integrin extracellular domains in outside-in and inside-out signaling. Cell. 2002; 110(5):599-11. [PubMed: 12230977]

125. Chen W, Lou J, Evans EA, Zhu C. Observing force-regulated conformational changes and ligand dissociation from a single integrin on cells. J Cell Biol. 2012; 199(3):497-512. DOI: 10.1083/jcb. 201201091 [PubMed: 23109670] 
126. Lavin Y, Winter D, Blecher-Gonen R, David E, Keren-Shaul H, Merad M, et al. Tissue-resident macrophage enhancer landscapes are shaped by the local microenvironment. Cell. 2014; 159(6): 1312-26. DOI: 10.1016/j.cell.2014.11.018 [PubMed: 25480296] 


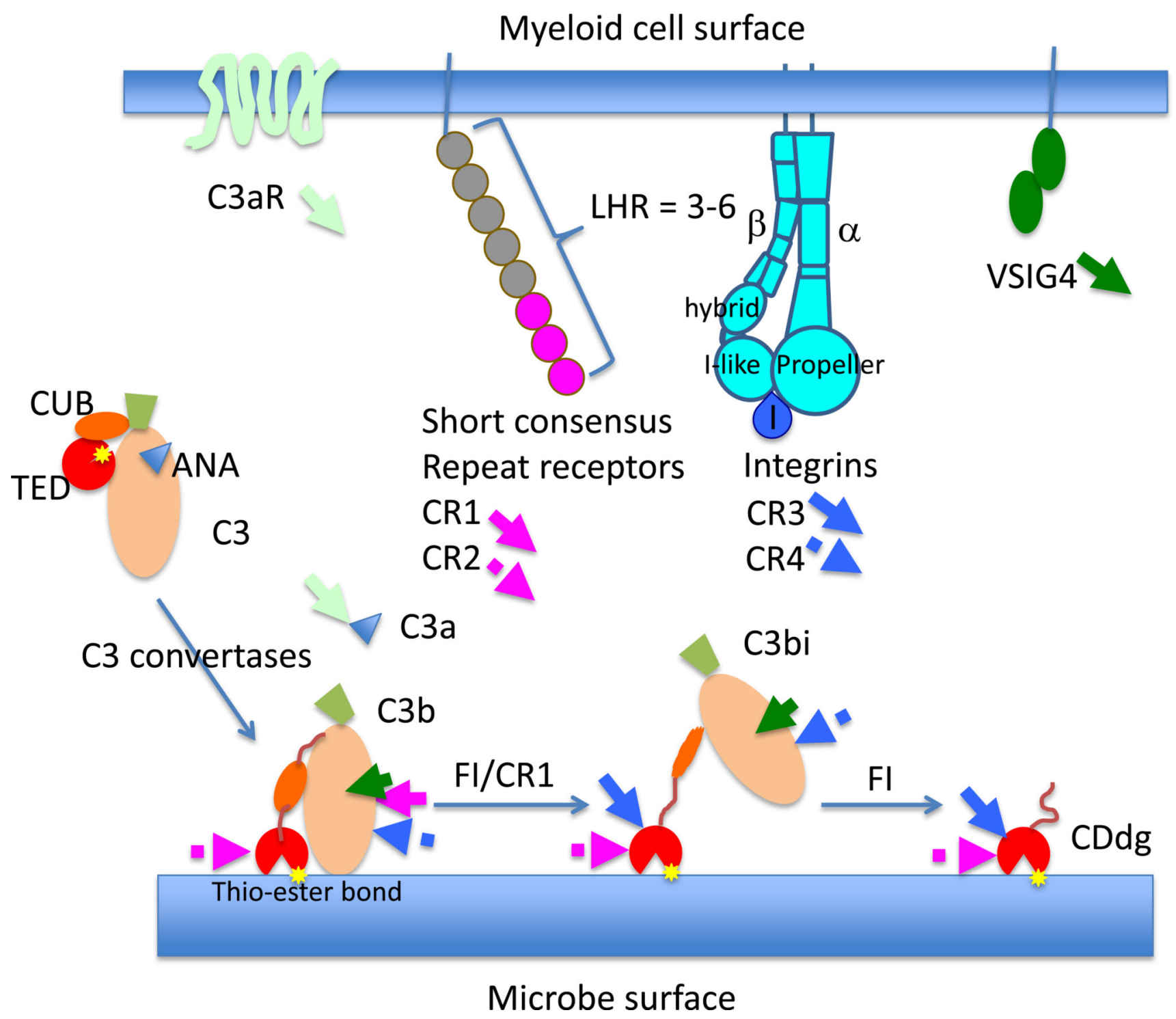

Figure 1.

Receptors for products of $3^{\text {rd }}$ component of complement (C3) expressed on human macrophages. Human macrophages differentiated from $\mathrm{CD} 14^{+}$monocytes with granulocytemonocyte colony stimulating factor express all the major complement receptors including C3aR, C5aR, CR1, CR3 and VSIG4. The arrows with the receptor names indicate approximate binding site location within schematic of $\mathrm{C} 3$ breakdown products that are released in the production of $\mathrm{C} 3 \mathrm{a}, \mathrm{C} 3 \mathrm{~b}$, and its covalently attached products iC $3 \mathrm{~b}$ and $\mathrm{C} 3 \mathrm{~d}$. The upper part of the schematic is the macrophage surface and the lower part is a microbial surface bearing the complement components. LHR = long homologous repeat. 


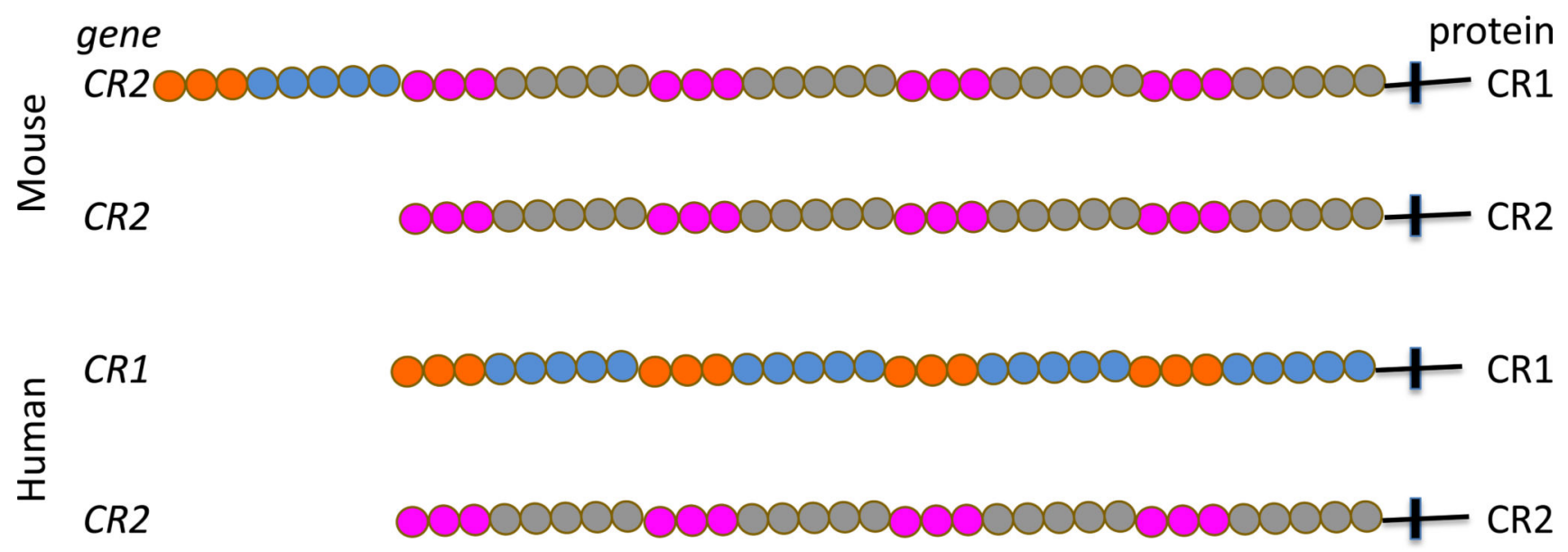

Figure 2.

Schematic of the mouse and human complement receptors gene products. In the mouse, CR1 and CR2 proteins are derived from alternative splicing of the $C r 2$ gene. Mouse CR 1 and CR2 are not present on myeloid cells. In humans, the CR1 and CR2 proteins are products of different genes. Human CR1 is expressed on myeloid cells and functions in phagocytosis in additional to clearance or immune complexes bearding $\mathrm{C} 3 \mathrm{~b}$ and/or C4b. CR1 also acts as a cofactor for factor $\mathrm{I}$ in conversion of $\mathrm{C} 3 \mathrm{~b}$ to $\mathrm{iC} 3 \mathrm{~b}$ and, further, to $\mathrm{C} 3 \mathrm{~d}$. Each ball is a short consensus repeat (SCR) and each group of 7 repeats referred to as a long homologous repeat (LHR). 


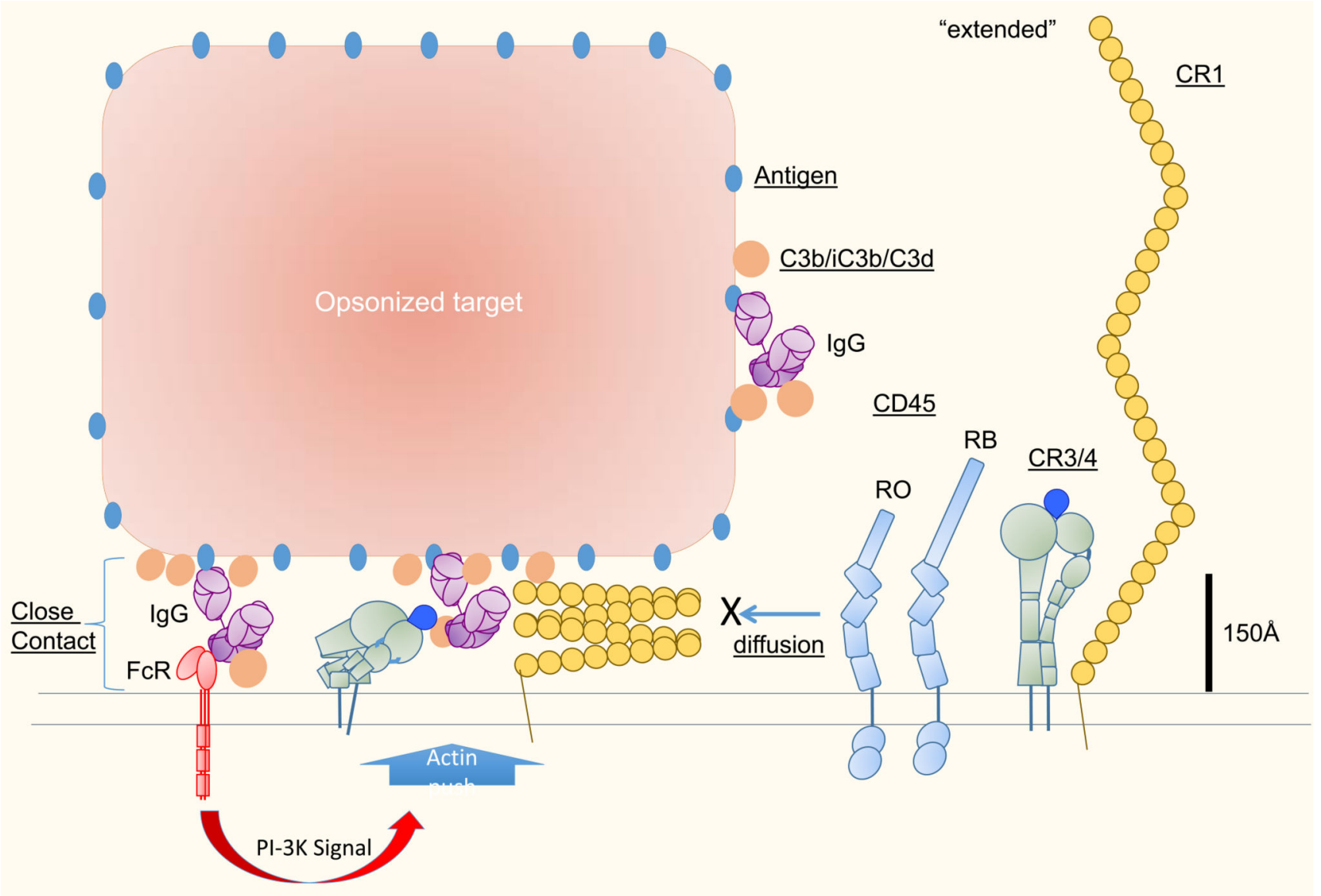

Figure 3.

Fitting integrins and complement receptors into diffusion barrier model for phagocytic synapse- Close contacts are inherent to immunological synapses. Fc receptors and T cell receptors naturally fit into a $15 \mathrm{~nm}$ gap that generates a diffusion barrier for entry of CD45 and thus tips the local kinase/phosphatase balance in favor of the kinases. Large receptors like CR3 and CR4 are too large to fit into the $<15 \mathrm{~nm}$ space when fully extended. Active Factin mediated processes can work with integrins to expand close contacts in phagocytic immune synapses and increase the area from which CD45 is excluded. The relevant integrin conformations that mediate this close contact formation are not known, but may include alternative crouching conformations recently described by electron microscopy, or tilted extended conformations generated by forces tangential to the membrane. CR 1 function overlaps extensively with CR3/4 and thus its possible that CR1 can also adopt conformations that facilitate close contact in an F-actin dependent manner, despite its apparent large size. Further study is needed to understand whether CR1 also participates in close contact formation and how the CR1's structure is adapted to this task. 
Table

Complement receptors involved in adhesion, migration and phagocytosis

\begin{tabular}{|c|c|c|c|c|}
\hline Protein & Gene(s) & Ligand(s) & Cells & Function \\
\hline $\mathrm{C} 3 \mathrm{aR}$ & $C 3 a R$ & $\mathrm{C} 3 \mathrm{a}$ & MF, DC, hN, hMC, hEO & Chemotaxis, Activation \\
\hline $\mathrm{C} 5 \mathrm{aR}$ & C5aR & $\mathrm{C} 5 \mathrm{a}$ & $\mathrm{MF}, \mathrm{MO}, \mathrm{N}, \mathrm{T}$ & Chemotaxis, Activation \\
\hline $\mathrm{CR} 1$ & $h C r 1 / m C r 2$ & $\mathrm{C} 3 \mathrm{~b}, \mathrm{C} 4 \mathrm{~b}$ & $\mathrm{~N}, \mathrm{EO}, \mathrm{BASO}, \mathrm{MF}$ & $\begin{array}{l}\text { IC clearance, } \mathrm{C} 3 \mathrm{~b} / \mathrm{C} 4 \mathrm{~b} \text { regulation, } \\
\text { Phagocytosis }\end{array}$ \\
\hline $\mathrm{CR} 2$ & $h C r 2 / m C r 2$ & $C 3 d$ & $\mathrm{~B}, \mathrm{FDC}$ & IC Capture \\
\hline \multirow[b]{2}{*}{ CR3 } & ITGAM & \multirow[b]{2}{*}{ iC3b, C3d, ICAM-1, Fibrinogen } & \multirow[b]{2}{*}{ MF, N, EO, BASO, DC, actT } & \multirow[b]{2}{*}{ Phagocytosis, Migration } \\
\hline & ITGB2 & & & \\
\hline \multirow[b]{2}{*}{ CR4 } & ITAGAX & \multirow{2}{*}{$\begin{array}{l}\text { iC } 3 b, \text { ICAM-1, ICAM-2, VCAM, } \\
\text { denatured proteins }\end{array}$} & \multirow[b]{2}{*}{$\mathrm{DC}, \mathrm{N}, \mathrm{MF}$, act T } & \multirow[b]{2}{*}{ Phagocytosis, Migration } \\
\hline & $I T G B 2$ & & & \\
\hline CRIg/VSIG4 & VSIG4 & $C 3 b, i C 3 b$ & MF, MC, Kupffer & IC clearance, Phagocytosis, Regulation \\
\hline
\end{tabular}

Key: B, B cell; Baso, basophil; DC, dendritic cell; EO, eosinophil; FDC, follicular dendritic cell; h, human; IC, immune complex; ICAM, intercellular adhesion molecule; m, mouse; MC, mast cell; MF, macrophage; MO, monocyte; N, neutrophil; T, T cell; VCAM, vascular cell adhesion molecule. 